\title{
Polyethylene Oxidation in Total Hip Arthroplasty: Evolution and New Advances
}

\author{
Enrique Gómez-Barrena ${ }^{*}, 1$, Francisco Medel $^{2}$ and José Antonio Puértolas ${ }^{3}$
}

\author{
${ }^{I}$ Fundación Jiménez Díaz, Universidad Autónoma de Madrid, Madrid, Spain \\ ${ }^{2}$ Materials Science and Technology Department-Instituto Ciencia de Materiales de Aragón, Universidad de Zaragoza- \\ CSIC, Spain \\ ${ }^{3}$ Materials Science and Technology Department-I3A, Instituto Ciencia de Materiales de Aragón, Universidad de \\ Zaragoza-CSIC, Spain
}

\begin{abstract}
Ultra-high molecular weight polyethylene (UHMWPE) remains the gold standard acetabular bearing material for hip arthroplasty. Its successful performance has shown consistent results and survivorship in total hip replacement (THR) above $85 \%$ after 15 years, with different patients, surgeons, or designs.

As THR results have been challenged by wear, oxidation, and liner fracture, relevant research on the material properties in the past decade has led to the development and clinical introduction of highly crosslinked polyethylenes (HXLPE). More stress on the bearing (more active, overweighted, younger patients), and more variability in the implantation technique in different small and large Hospitals may further compromise the clinical performance for many patients. The long-term in vivo performance of these materials remains to be proven. Clinical and retrieval studies after more than 5 years of in vivo use with HXLPE in THR are reviewed and consistently show a substantial decrease in wear rate. Moreover, a second generation of improved polyethylenes is backed by in vitro data and awaits more clinical experience to confirm the experimental improvements. Also, new antioxidant, free radical scavengers, candidates and the reinforcement of polyethylene through composites are currently under basic research.
\end{abstract}

Oxidation of polyethylene is today significantly reduced by present formulations, and this forgiving, affordable, and wellknown material is still reliable to meet today's higher requirements in total hip replacement.

Keywords: UHMWPE, HXLPE, cross-linked polyethylene, polyethylene, oxidation, total hip arthroplasty.

\section{INTRODUCTION}

Polyethylene is a well-known material to orthopaedic surgeons since Sir John Charnley popularized it in his hip LFA (low friction arthroplasty) [1]. The rationale under the use of this polymer has been extensively reviewed [2], with clear advantages over other polymers used in early total hip arthroplasty (THA) designs, such as Teflon (polytetrafluorethylene, PTFE) and Delrin (polyacetal). Polyethylene and ultra high molecular weight polyethylene (UHMWPE), became the most popular and standard material in THA friction pairs since the 1960's until the 1990's. Early alternative solutions based on metal-on-metal (MOM) or ceramic-on-ceramic (COC) articulations showed significant pitfalls in many designs $[3,4]$. The standardized solution of UHMWPE for the acetabulum was at the time inexpensively processed by machining components out of extruded UHMWPE bars, followed by gamma irradiation sterilization of large batchs to doses ranging from 25 to $40 \mathrm{KGy}$. It is worth observing that UHMWPE is a semicrystalline polymer

*Address correspondence to this author at the Servicio de Cirugía Ortopédica y Traumatología, Fundación Jiménez Díaz, Universidad Autónoma de Madrid, Avda Reyes Católicos 2, Madrid 28040, Spain; Tel: +34.915504827; Fax: +34.915431071;

E-mail: enrique.gomezbarrena@uam.es constituted by a crystalline phase (the crystals, observed in the transmission electron microscopy -TEM- images as lamellae) and an amorphous phase (the disordered state) that allows some rearrangement of the crystals under mechanical stresses [5]. This characteristic semicrystalline structure of UHMWPE is illustrtated in Fig. (1). The material had a significantly large molecular weight (ultra-high), meaning long polymer chains that were further reinforced by covalent molecular bridges, also known as cross-links, originated upon gamma irradiation.

In the 1980's and early 1990's, long-term survivorship of polyethylene cups was compromised by osteolysis and aseptic loosening. After significant research, wear particle production was found the triggering mechanism. Cement particles were first considered as the causative agent, the so called "cement disease", but when the osteolysis also prevailed in uncemented designs, polyethylene particles were apparent as the main pathogenetic factor, particularly those in the submicron range. Aseptic loosening and osteolysis resulted in significant concern about polyethylene quality and wear resistance in the Orthopaedic community, and extensive research was devoted to clarify what caused the polyethylene failure and how to prevent it. Unimplanted polyethylene components from the shelf were analyzed to investigate the material prior to in vivo use, and subsurface white bands of high density material (Fig. 2) were 
found in components with long shelf life [6,7]. Retrieval studies of long-term failures of polyethylene cups showed that polyethylene was not homogeneous. Occasional subsurface white bands and fusion defects in the bulk material were frequently identified in acetabular polyethylene components. Further analysis to correlated these findings with wear and performance [8], but while consolidating defects were found more frequently in early-retrieved cups without affecting survivorship, subsurface defects were found responsible for material loss at the articulating surface. Fourier transformed infra red (FTIR) analysis of the material from the surface to the bulk [9] confirmed that oxidized polyethylene was the constituent of this white band defects. Mechanical analysis of this material showed a comparatively brittle behavior with respect to non-oxidized polyethylene, as well as distinct fracture modes [10].

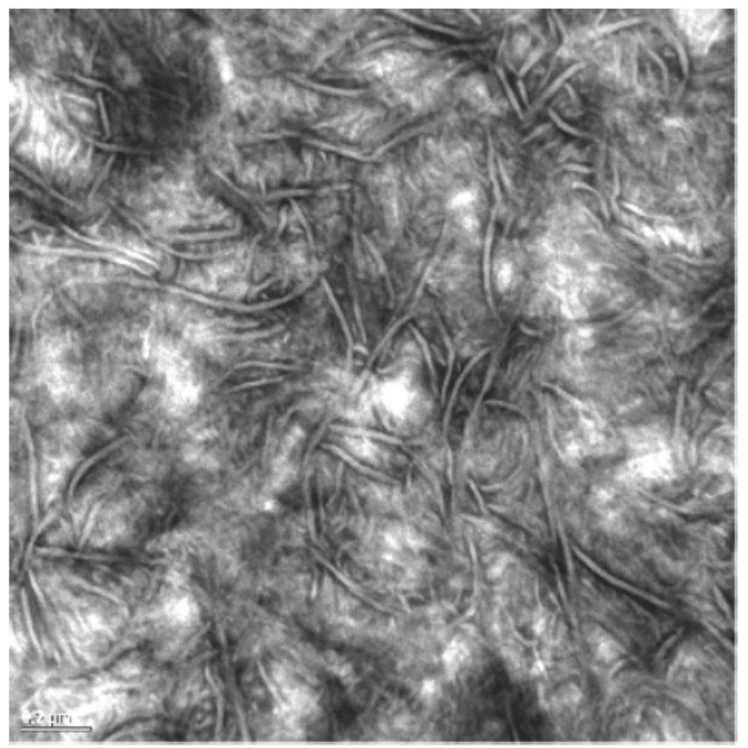

Fig. (1). UHMWPE is a semicrystalline polymer with crystalline and amorphous regions. Crystals appear as ribbon-like lamellae and amorphous regions as gray areas in Transmission Electron Micrographs.

From these and other findings, it was concluded that oxidation of the polyethylene component concentrated in the subsurface in long shelf aged implants and was deleterious for the performance of the joint.

\section{CAUSES AND AVOIDANCE OF OXIDATION IN CONVENTIONAL POLYETHYLENE}

Oxidation of irradiated polyethylene is unavoidable as soon as the polymer is in contact with air or in vivo fluids. Eventually, several groups and particularly Costa et al. [9, 11] characterized the oxidation in failed and never implanted polyethylene components. The oxidation in never implanted components was more intense with longer times on the shelf before implantation [6,7], and chemical studies confirmed that irradiation (gamma irradiation was the standard procedure of sterilization) in the presence of oxygen led to chain scission of the polyethylene long chain and free radical generation at the crystal surfaces [12]. In view of the semicrystalline structure of the material that determines many mechanical properties, any change in the microstructure may significantly alter the mechanical behavior of the material [5].

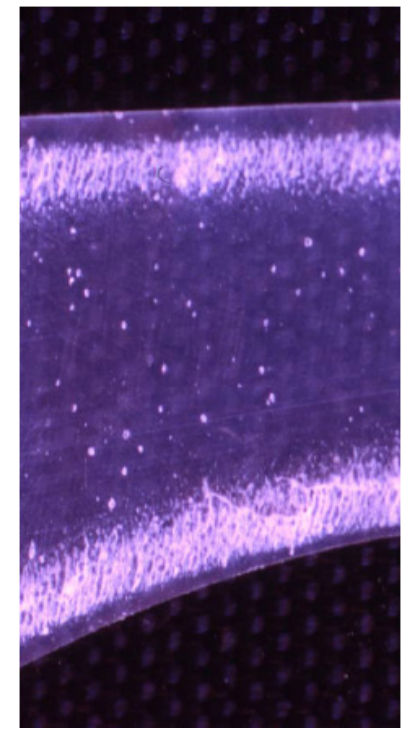

Fig. (2). After long shelf life (5 years) of a gamma irradiated in air conventional polyethylene component, a subsurface white band is clearly detected.

The oxidative degradation of the material progressed in the presence of oxygen after the irradiation process within the permeable package, while the component was sitting on the shelf. To eliminate oxygen out of the system is not an easy task, but the first reaction of the Orthopaedic community was to standardize barrier packaging to avoid oxygen permeability, and thus perform gamma irradiation sterilization either in vacuum or in the presence of inert gases (typically, nitrogen, and argon), and to recommend the avoidance of implantation 5 years after manufacture and irradiation [13]. Other non-penetrating sterilization methods, such as ethylene oxide or gas plasma, were reconsidered and reincorporated to the process, although ethylene oxide was originally discontinued because of the cumbersomeness of its method. Irradiation was discovered as a valuable technique not only for efficient sterilization, but also for crosslinking of the polyethylene chains.

Although the previous efforts generally succeeded in avoiding shelf aging, there has been growing evidence of the occurrence of in vivo oxidation of polyethylene components, not only after gamma sterilization in air, but also following gamma sterilization in nitrogen $[13,14]$. Furthermore, in vivo oxidized polyethylene retrievals (Fig. 3) display a characteristic regional pattern, with regions protected by metal parts (bearing surface and backside) reaching lower oxidation than more exposed areas (rim) [13-16]. The unavoidable occurrence of in vivo oxidation in gamma sterilized polyethylene components stems from postirradiation induced free radicals, which, upon oxygen availability, initiate the oxidation cycle and the associated physical changes.

\section{NEW POLYETHYLENES TO DECREASE WEAR}

The development of first-generation highly crosslinked polyethylene formulations were intended to provide medical grade UHMWPEs with an extremely high wear resistance and good oxidative stability. Thus, high doses of gamma or electron beam radiation are employed to promote an elevated 
(1)

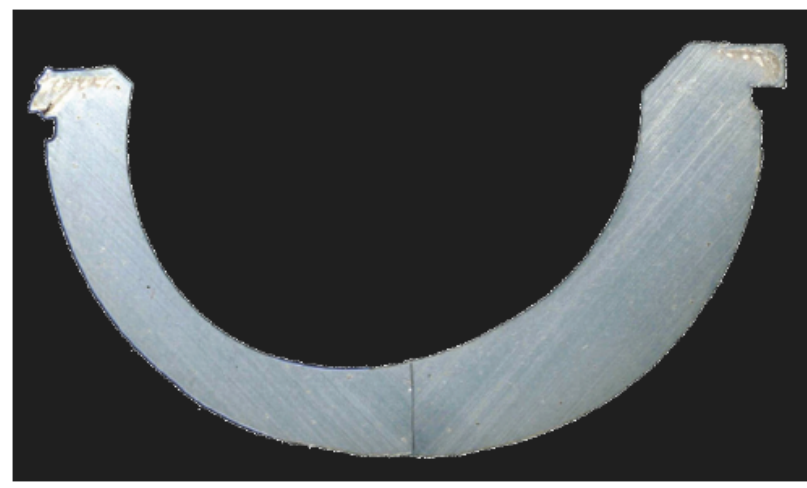

(2)

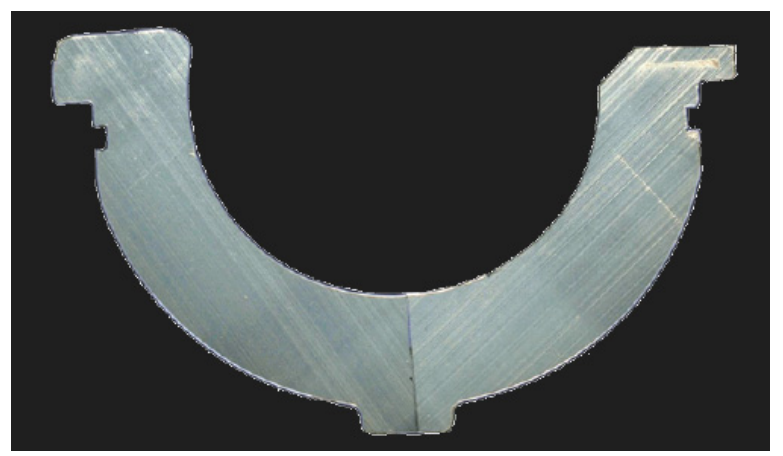

Fig. (3). After in vivo exposure, high oxidation areas are seen as a subsurface white band in cross-sections of a gamma air (1) and gamma inert (2) sterilized acetabular liner retrievals. Images courtesy of Professor Steven Kurtz (Implant Research Center. Drexel University. Philadelphia). crosslink density (i.e. covalent bonds) into UHMWPE, which, in turn, is responsible for a notable increase in wear resistance. In first-generation highly crosslinked polyethylenes, two different approaches were adopted to achieve oxidation resistance. First, annealing, involved a single thermal treatment below the melting temperature of UHMWPE so that crystallinity and mechanical properties were preserved [17]. However, the commercial highly crosslinked polyethylene obtained by gamma irradiation, annealing and finally gamma inert sterilization contained residual free radicals with the potential to oxidize in vivo [15]. The second approach was based on post-irradiation remelting of the polymer above the crystalline transition. This strategy allowed for elimination of free radicals up to undetectable levels, but at the expense of crystallinity changes and diminished mechanical properties $[17,18]$.

\section{IN VIVO AND RETRIEVAL STUDIES ON HXLPES}

From a wear perspective, radiographic and retrieval studies have confirmed a significantly reduced femoral head penetration for both annealed and remelted HXLPE in the first decade of implantation [19-30]. Table 1 offers a summary the significant papers. Not only clinical mid-term follow-up studies clearly show this wear rate decrease, but more precise methods such as roentgen stereogrammetry analysis (RSA) confirms this important finding in threedimensional evaluation of cups in randomized studies (Table 2).

Regarding the clinical failure modes, the revision rates of acetabular liners of both first-generation HXLPE formulations due to loosening, instability and infection remain comparable to those of conventional gamma inert

Table 1. Summary of Significant Clinical Studies Confirming a Wear Rate Decrease with 1st Generation HXLPE in the Mid-Term Follow-Up

\begin{tabular}{|c|c|c|c|c|c|c|}
\hline Study & $\begin{array}{l}\text { Design and } \\
\text { Follow-up }\end{array}$ & HXLPE & HEAD & Follow-Up & $\begin{array}{l}\text { Mean Wear Rate } \mathbf{m m} / \mathbf{y r} \\
\text { (After Bedding-In) }\end{array}$ & $\begin{array}{l}\text { Wear Rate } \\
\text { Decrease }\end{array}$ \\
\hline $\begin{array}{l}\text { Dorr et al. } \\
\text { JBJS A } \\
2005\end{array}$ & $\begin{array}{l}\text { Prospective, } \\
\text { cohorts } \\
37 \text { hips } / 37\end{array}$ & $\begin{array}{c}\text { Durasul } \\
95 \mathrm{kGy} \text {, remelted }\end{array}$ & $28 \mathrm{~mm} \mathrm{CrCo}$ & 5 years & 0.029 vs 0.065 & $45 \%$ \\
\hline $\begin{array}{l}\text { D'Antonio } \\
\text { et al. } \\
\text { CORR } 2005\end{array}$ & $\begin{array}{c}\text { Retrospective, } \\
\text { comparative } \\
56 \text { hips } / 53\end{array}$ & $\begin{array}{l}\text { Crossfire } \\
105 \mathrm{KGy}, \\
\text { annealed }\end{array}$ & $28 \mathrm{~mm} \mathrm{CrCo}$ & $\begin{array}{l}\text { Mean } 5 \mathrm{yr} \\
(\min 4)\end{array}$ & 0.036 vs 0.131 & $72 \%$ \\
\hline $\begin{array}{l}\text { Engh et al. } \\
\text { J Arthr } 2006\end{array}$ & $\begin{array}{l}\text { Prospective, } \\
\text { randomized } \\
208 \text { hips }\end{array}$ & $\begin{array}{c}\text { Marathon } \\
50 \mathrm{kGy} \text {, remelted }\end{array}$ & $28 \mathrm{~mm} \mathrm{CrCo}$ & $\begin{array}{c}5.7 \mathrm{yr} \\
(4.1-7.2)\end{array}$ & 0.01 vs 0.19 & $95 \%$ \\
\hline $\begin{array}{c}\text { Olyslaegers } \\
\text { et al. } \\
\text { J Arthr } 2008\end{array}$ & $\begin{array}{c}\text { Case-control } \\
\text { with } \\
\text { historical } \\
60 \text { hips } / 20\end{array}$ & $\begin{array}{l}\text { Longevity } \\
100 \mathrm{KGy} \text {, remelted }\end{array}$ & $28 \mathrm{~mm} \mathrm{CrCo}$ & $\begin{array}{c}\text { XLPE } 5.06 \mathrm{yr} \\
(52-69 \mathrm{mo}), \\
\text { Std PE } 5.1 \mathrm{yr} \\
(55-79)\end{array}$ & 0.05 vs 0.101 & $50 \%$ \\
\hline $\begin{array}{c}\text { García-Rey } \\
\text { et al. } \\
\text { J BJS-B } 2008\end{array}$ & $\begin{array}{l}\text { Prospective, } \\
\text { randomized } \\
45 \text { hips } / 45\end{array}$ & $\begin{array}{c}\text { Durasul } \\
95 \mathrm{kGy} \text {, remelted }\end{array}$ & $28 \mathrm{~mm} \mathrm{CrCo}$ & $\begin{array}{l}66.3 \mathrm{mo} \\
(60-92)\end{array}$ & 0.006 vs 0.038 & $84.3 \%$ \\
\hline $\begin{array}{l}\text { Geerdink } \\
\text { et al. } \\
\text { CORR } 2009\end{array}$ & $\begin{array}{l}\text { Randomized, } \\
\text { double blind } \\
17 \text { hips/23 }\end{array}$ & $\begin{array}{l}\text { Duration } \\
30 \mathrm{KGy}, \\
\text { annealed }\end{array}$ & $28 \mathrm{~mm} \mathrm{CrCo}$ & $\begin{array}{l}\text { Mean } 8 y r \\
(7-9)\end{array}$ & 0.088 vs 0.142 & $38 \%$ \\
\hline
\end{tabular}


Table 2. Clinical Studies with 3D Analysis of Wear Rate with 1st Generation HXLPE

\begin{tabular}{|c|c|c|c|c|c|}
\hline Study & Design & HXLPE & Head & Follow-Up & Conclusions \\
\hline $\begin{array}{l}\text { Bragdon et al. } \\
\text { J Arthrop 2007 } \\
\text { (EFORT ‘09) }\end{array}$ & $\begin{array}{c}\text { Non-consecutive, } \\
\text { non-randomized } \\
30 \text { hips }\end{array}$ & $\begin{array}{l}\text { Longevity } 100 \\
\text { kGy, remelted }\end{array}$ & $\begin{array}{c}28 \mathrm{mmCrCo}(16 \mathrm{hips}) v s \\
36 \mathrm{mmCrCo} \\
\text { (14 hips) }\end{array}$ & $\begin{array}{l}3 \text { years } \\
\text { EFORT 09: } \\
7-10 \mathrm{yr}\end{array}$ & $\begin{array}{l}\text { No diff 3D between } \\
28 \text { and } 36 \mathrm{~mm}\end{array}$ \\
\hline $\begin{array}{l}\text { Röhrl et al. } \\
\text { Acta Orthop } \\
2007\end{array}$ & $\begin{array}{l}\text { Retrospective, } \\
\text { comparative } \\
56 \text { hips } / 53\end{array}$ & $\begin{array}{l}\text { Crossfire } \\
105 \text { KGy, } \\
\text { annealed }\end{array}$ & $28 \mathrm{~mm} \mathrm{CrCo}$ & $\begin{array}{c}\text { XLPE } 6 \mathrm{yr} \text {, Std } 5 \\
\mathrm{yr}\end{array}$ & $\begin{array}{l}\text { No wear rate progression at } 6 \mathrm{yr} \\
\text { re oxidation }\end{array}$ \\
\hline $\begin{array}{l}\text { Digas et al. } \\
\text { Acta Orthop } \\
2007 \text { (cem) }\end{array}$ & $\begin{array}{l}\text { Prospective, } \\
\text { randomized } \\
56 \text { hips }\end{array}$ & $\begin{array}{c}\text { Durasul } \\
95 \mathrm{kGy}, \text { remelted }\end{array}$ & $28 \mathrm{~mm} \mathrm{CrCo}$ & 5 years & $\begin{array}{c}0.001 \text { vs } \\
0.06 \mathrm{~mm} / \mathrm{yr}(3 \mathrm{D})(98 \% \\
\text { decrease) }\end{array}$ \\
\hline $\begin{array}{l}\text { Digas et al. } \\
\text { Acta Orthop } \\
2007 \text { (hybr) }\end{array}$ & $\begin{array}{l}\text { Prospective, } \\
\text { randomized } \\
\text { contralat control } \\
32 \text { hips/32 }\end{array}$ & $\begin{array}{l}\text { Longevity } \\
100 \mathrm{KGy} \text {, } \\
\text { remelted }\end{array}$ & $28 \mathrm{~mm} \mathrm{CrCo}$ & 5 years & $\begin{array}{c}0.00 v \mathrm{v} \\
0.057 \mathrm{~mm} / \mathrm{yr}(3 \mathrm{D}) \\
(99-100 \% \text { decrease })\end{array}$ \\
\hline $\begin{array}{l}\text { Glyn-Jones et al. } \\
\text { J Arthrop } \\
2008\end{array}$ & $\begin{array}{l}\text { Prospective, doub- } \\
\text { blind, rand, } \\
\text { controlled } \\
26 \text { hips } / 25\end{array}$ & $\begin{array}{l}\text { Longevity } \\
100 \mathrm{KGy} \text {, } \\
\text { remelted }\end{array}$ & $28 \mathrm{~mm} \mathrm{CrCo}$ & 2 years & $\begin{array}{c}0.06 \mathrm{~mm} / \mathrm{yr} \text { vs } 0.10(3 \mathrm{D}) \\
(40 \% \text { decrease })\end{array}$ \\
\hline
\end{tabular}

sterilized liners after a decade of service [19]. Recent retrievals studies have confirmed that annealed highly crosslinked polyethylene acetabular liners oxidize in vivo (Fig. 3) and that, in some cases, exhibit damage at nonarticulating areas $[19,30,31]$. Thus, delamination, subsurface cracking and even partial fracture of the rim have been observed under relatively unusual clinical circumstances, that is recurrent dislocations, trauma or edge loading [30]. Furthermore, according to a consecutive series of retrieved annealed HXLPE acetabular liners, the incidence of rim damage secondary to in vivo oxidation and mechanical loading appears to be as low as 5\% [30]. Although remelted HXLPE acetabular liner retrievals exhibit near-zero oxidation levels after a decade of in vivo exposure, rapid crack initiation and rim fracture cases have also been reported because of the combination of decreased mechanical strength [32-34]. Nevertheless, the incidence of rim fracture in remelted retrievals appears to be as low as that of retrieved annealed liners [19]. Very recently, the hypothesized complete oxidative stability of remelted HXLPE components has been questioned in view of the increasing trend of oxidation with implantation time observed in retrievals and elevated oxidation measured after ex vivo aging studies $[19,35]$.

\section{PRESENT AND FUTURE SOLUTIONS TO OXIDATION}

The clinical performance of first-generation HXLPE will need further research to confirm the benefits of the reduction in femoral head penetration and the clinical relevance, if any, of in vivo oxidation and crack initiation in the long-term, during the second decade of implantation. Currently, secondgeneration HXLPEs represent a promising alternative to first-generation HXLPEs as they take advantage of alternative stabilization strategies, such as natural antioxidants (vitamin E), mechanical annealing, or sequential irradiation and annealing processes [36-41].

In the sequentially annealed material, experimental studies proved that $4.9 \mathrm{~mm}$ thickness maintains a similar wear rate than thicker components, thus confirming thin components are not disadvantageous under this formulation [42], and support larger heads without more damage near impingement [43].

As for the vitamin E stabilized material, different formulations are produced either when the antioxidant is blended with the polyethylene at the time of consolidation, or if vitamin $\mathrm{E}$ diffuses through the consolidated polymer in the mechanism of doping. A gradient distribution of antioxidant is typically associated with the diffusion method, but polyethylene oxidation is controlled by vitamin $\mathrm{E}$, as shown after 36 months of artificial aging [44], and the postirradiation oxidation decreases with increasing vitamin $\mathrm{E}$ concentrations [45]. On the other hand, the vitamin E blended formulation $(<0.1 \%$ of vitamin $\mathrm{E}$ in weight) has been shown to maintain the mechanical properties of polyethylene [46].

Other antioxidant strategies are under development, using different free radical scavengers, such as nitroxide-TEMPO (2,2,6,6-Tetramethylpiperidine-1-oxyl) [47], HPAO (hindered phenol antioxidant) [48], or anthocyanin extracts [49]. Last but not least nanoscale modifications are also being studied to reinforce the polyethylene, namely composite reinforcement by multiwalled carbon nanotubes [50], or grafting with 2-methacryloyloxyethyl phosphorylcholine polymer [51] among others. Needless to say that the ongoing refinement into the polyethylene basic science and proposals will not stand until full developments are ready, and experimental and clinical data prove the concept and solidity of new polyethylene formulations. The oxidative resistance and mechanical performance of this last generation HXLPE are 
promising based on in vitro testing of the most advanced products, such as sequential annealing and vitamin $\mathrm{E}$ blended or diffused polyethylenes, but their impact in the clinical practice needs to be established.

\section{REFERENCES}

[1] Charnley J. Arthroplasty of the hip. A new operation. Lancet 1961; 1(7187): 1129-32.

[2] Li S, Burstein AH. Ultra-high molecular weight polyethylene. The material and its use in total joint implants. J Bone Joint Surg Am 1994; 76(7): 1080-90.

[3] Cuckler JM. The rationale for metal-on-metal total hip arthroplasty. Clin Orthop Relat Res 2005; 441: 132-6.

[4] Garcia-Cimbrelo E, Martinez-Sayanes JM, Minuesa A, Munuera L. Mittelmeier ceramic-ceramic prosthesis after 10 years. J Arthroplasty 1996; 11(7): 773-81.

[5] Medel FJ, Garcia-Alvarez F, Gomez-Barrena E, Puertolas JA. Microstructure changes of extruded ultra high molecular weight polyethylene after gamma irradiation and shelf-aging. Polymer Degrad Stab 2005; 88(3): 435-43.

[6] Li S, Chang JD, Barrena EG, Furman BD, Wright TM, Salvati E. Nonconsolidated polyethylene particles and oxidation in Charnley acetabular cups. Clin Orthop Relat Res 1995; 319: 54-63.

[7] Currier BH, Currier JH, Collier JP, Mayor MB, Scott RD. Shelf life and in vivo duration. Impacts on performance of tibial bearings. Clin Orthop Relat Res 1997; 342: 111-22.

[8] Gomez-Barrena E, Li S, Furman BS, Masri BA, Wright TM, Salvati EA. Role of polyethylene oxidation and consolidation defects in cup performance. Clin Orthop Relat Res 1998; 352: 10517.

[9] Costa L, Luda MP, Trossarelli L, Brach del Prever EM, Crova M, Gallinaro P. Oxidation in orthopaedic UHMWPE sterilized by gamma-radiation and ethylene oxide. Biomaterials 1998; 19(7-9): 659-68.

[10] Puertolas JA, Larrea A, Gomez-Barrena E. Fracture behavior of UHMWPE in non-implanted, shelf-aged knee prostheses after gamma irradiation in air. Biomaterials 2001; 22(15): 2107-14.

[11] Costa L, Luda MP, Trossarelli L, Brach del Prever EM, Crova M, Gallinaro P. In vivo UHMWPE biodegradation of retrieved prosthesis. Biomaterials 1998; 19(15): 1371-85.

[12] Premnath V, Harris WH, Jasty M, Merrill EW. Gamma sterilization of UHMWPE articular implants: An analysis of the oxidation problem. Biomaterials 1996; 17(18): 1741-53.

[13] Medel FJ, Kurtz SM, Hozack WJ, et al. Gamma inert sterilization: a solution to polyethylene oxidation? J Bone Joint Surg 2009; 91(4): 839-49.

[14] Currier BH, Currier JH, Mayor MB, Lyford KA, Van Citters DW, Collier JP. In vivo oxidation of gamma-barrier-sterilized ultra-highmolecular-weight polyethylene bearings. J Arthroplasty 2007; 22(5): 721-31.

[15] Kurtz SM, Hozack WJ, Purtill JJ, et al. Otto Aufranc Award paper - Significance of in vivo degradation for polyethylene in total hip arthroplasty. Clin Orthop Relat Res 2006; 453: 47-57.

[16] Kurtz SM, Rimnac CM, Hozack WJ, et al. In vivo degradation of polyethylene liners after gamma sterilization in air. J Bone Joint Surg Am 2005; 87A(4): 815-23.

[17] Medel FJ, Pena P, Cegonino J, Gomez-Barrena E, Puertolas JA. Comparative fatigue behavior and toughness of remelted and annealed highly crosslinked polyethylenes. J Biomed Mater Res B Appl Biomater 2007; 83B(2): 380-90.

[18] Puertolas JA, Medel FJ, Cegonino J, Gomez-Barrena E, Rios R. Influence of the remelting process on the fatigue behavior of electron beam irradiated UHMWPE. J Biomed Mater Res B Appl Biomater 2006; 76B(2): 346-53.

[19] Kurtz S, Medel FJ, MacDonald D, Rimnac CM. In vivo oxidation, oxidation potential, and clinical performance of highly crosslinked UHMWPEs implanted for up to 8 years. 4th International Meeting UHMWPE for arthroplasty: From Powder to Debris; 2009; Torino, Italy. 2009.

[20] Digas G, Karrholm J, Thanner J, Herberts P. 5-year experience of highly cross-linked polyethylene in cemented and uncemented sockets: Two randomized studies using radiostereometric analysis. Acta Orthop 2007; 78(6): 746-54.

[21] Bragdon CR, Jasty M, Muratoglu OK, Harris WH. Third-body wear testing of a highly cross-linked acetabular liner - The effect of large femoral head size in the presence of particulate poly (methylmethacrylate) debris. J Arthroplasty 2005; 20(3): 379-85.

[22] D'Antonio JA, Manley MT, Capello WN, et al. Five-year experience with Crossfire highly cross-linked polyethylene. Clin Orthop Relat Res 2005; 441: 143-50.

[23] Engh CA, Stepniewski AS, Ginn SD, et al. A randomized prospective evaluation of outcomes after total hip arthroplasty using cross-linked marathon and non-cross-linked Enduron polyethylene liners. J Arthroplasty 2006; 21(6): 17-25.

[24] Olyslaegers C, Defoort K, Simon JP, Vandenberghe L. Wear in conventional and highly cross-linked polyethylene cups: a 5-year follow-up study. J Arthroplasty 2008; 23(4): 489-94.

[25] Garcia-Rey E, Garcia-Cimbrelo E, Cruz-Pardos A, OrtegaChamarro J. New polyethylenes in total hip replacement: a prospective, comparative clinical study of two types of liner. J Bone Joint Surg Br 2008; 90(2): 149-53.

[26] Geerdink CH, Grimm B, Vencken W, Heyligers IC, Tonino AJ. Cross-linked compared with historical polyethylene in THA: An 8year clinical study. Clin Orthop Relat Res 2009; 467(4): 979-84.

[27] Bragdon CR, Greene ME, Freiberg AA, Harris WH, Malchau H. Radiostereometric analysis comparison of wear of highly crosslinked polyethylene against $36-v s \quad 28-\mathrm{mm}$ femoral heads. J Arthroplasty 2007; 22(6): 125-9.

[28] Rohrl SM, Li MG, Nilsson KG, Nivbrant B. Very low wear of nonremelted highly cross-linked polyethylene cups: An RSA study lasting up to 6 years. Acta Orthop 2007; 78(6): 739-45.

[29] Glyn-Jones S, Isaac S, Hauptfleisch J, McLardy-Smith P, Murray DW, Gill HS. Does highly cross-linked polyethylene wear less than conventional polyethylene in total hip arthroplasty? A doubleblind, randomized, and controlled trial using roentgen stereophotogrammetric analysis. J Arthroplasty 2008; 23(3): 33743.

[30] Kurtz SM, Austin MS, Azzam K, et al. Mechanical properties, oxidation, and clinical performance of retrieved highly cross-linked crossfire liners after intermediate-term implantation. J Arthroplasty 2009 [Epub ahead of print].

[31] Currier BH, Currier JH, Mayor MB, Lyford KA, Collier JP, Van Citters DW. Evaluation of oxidation and fatigue damage of retrieved crossfire polyethylene acetabular cups. J Bone Joint Surg Am 2007; 89A(9): 2023-9.

[32] Duffy GP, Wannomae KK, Rowell SL, Muratoglu OK. Fracture of a cross-linked polyethylene liner due to impingement. J Arthroplasty 2009; 24(1): 158-e15-9.

[33] Tower SS, Currier JH, Currier BH, Lyford KA, Van Citters DW, Mayor MB. Rim cracking of the cross-linked longevity polyethylene acetabular liner after total hip arthroplasty. J Bone Joint Surg Am 2007; 89A(10): 2212-7.

[34] Moore KD, Beck PR, Petersen DW, Cuckler JM, Lemons JE, Eberhardt AW. Early failure of a cross-linked polyethylene acetabular liner a case report. J Bone Joint Surg Am 2008; 90A(11): 2499-504.

[35] Muratoglu OK. New findings with first generation highly crosslinked UHMWPE. 4th International Meeting UHMWPE for arthroplasty: From powder to debris; 2009; Torino, Italy 2009.

[36] Bracco P, Brunella V, Zanetti M, Luda MP, Costa L. Stabilisation of ultra-high molecular weight polyethylene with Vitamin E. Polymer Degrad Stab 2007; 92(12): 2155-62.

[37] Oral E, Rowell SL, Muratoglu OK. The effect of alpha-tocopherol on the oxidation and free radical decay in irradiated UHMWPE. Biomaterials 2006; 27(32): 5580-7.

[38] Oral E, Wannomae KK, Rowell SL, Muratoglu OK. Diffusion of vitamin $\mathrm{E}$ in ultra-high molecular weight polyethylene. Biomaterials 2007; 28(35): 5225-37.

[39] Kurtz SM, Dumbleton J, Siskey RS, Wang A, Manley M. Trace concentrations of vitamin $\mathrm{E}$ protect radiation crosslinked UHMWPE from oxidative degradation. J Biomed Mater Res A 2009; 90(2): 549-63.

[40] Wang AG, Yau SS, Essner A, Herrera L, Manley M, Dumbleton J. A highly crosslinked UHMWPE for CR and PS total knee arthroplasties. J Arthroplasty 2008; 23(4): 559-66.

[41] Kurtz SM, Mazzucco D, Rimnac CM, Schroeder D. Anisotropy and oxidative resistance of highly crosslinked UHMWPE after deformation processing by solid-state ram extrusion. Biomaterials 2006; 27(1): 24-34.

[42] Herrera L, Essner A, Loving L, Wang A. Hip simulator evaluation of the effect of liner thickness on the wear of sequentially 
crosslinked acetabular liners. 55 ${ }^{\text {th }}$ Annual Meeting of the Orthopaedic Research Society; Las Vegas, NV 2009; pp. 2336.

[43] Kelly NH, Rajadhyaksha AD, Wright TM, Maher SA, Westrich $\mathrm{GH}$. The effect of liner thickness on the wear of highly cross-linked polyethylene acetabular components under "near-impingement" conditions. 55th Annual Meeting of the Orthopaedic Research Society; 2009; Las Vegas, NV 2009; p. 2315.

[44] Rowell SL, Oral E, Muratoglu OK. Three-Year Real-Time Aging of Vitamin E-diffused, Radiation Cross-linked UHMWPE. 55th Annual Meeting of the Orthopaedic Research Society; Las Vegas, NV 2009; p. 21.

[45] Costa L, Bracco PM, Carpentieri I, V.; B, Brach del Prever EM. On post-irradiation oxidation of Vitamin E-stabilized UHMWPE. $55^{\text {th }}$ Annual Meeting of the Orthopaedic Research Society; Las Vegas, NV 2009; p. 461.

[46] Yau S-S, Le K-P, Wang A. Doping Vitamin E by Diffusion Deteriorates Properties of Crosslinked UHMWPE: Verified by Experiments. $55^{\text {th }}$ Annual Meeting of the Orthopaedic Research Society; Las Vegas, NV 2009; p. 458.
[47] Chumakov MC, Silverman J, Al-Sheikhly M. The Novel Scavenging of Free Radicals in UHMWPE with TEMPO, a Nitroxide Antioxidant. 55 ${ }^{\text {th }}$ Annual Meeting of the Orthopaedic Research Society; Las Vegas, NV 2009; p. 453.

[48] King R, Narayan VS, Ernsberger C, Hanes M. Characterization of Gamma-Irradiated UHMWPE Stabilized with a Hindered-Phenol Antioxidant. 55 ${ }^{\text {th }}$ Annual Meeting of the Orthopaedic Research Society; Las Vegas, NV 2009.

[49] He S, Le K-P, Blitz JW, Yau S-S, Korduba LA, A. W Anthocyanin doped UHMWPE: oxidation, wear and mechanical properties. $55^{\text {th }}$ Annual Meeting of the Orthopaedic Research Society; Las Vegas, NV 2009; pp. 451.

[50] Martinez-Morlanes MJ, Castell P, Martinez V, et al. Reinforced ultra-high molecular weight composite by carbon nanotube and gamma irradiation. 4th UHMWPE for arthroplasty: From powder to debris; Torino, Italy 2009.

[51] Kyomoto M, Moro T, Miyaji F, et al. High-density brush-like structure mimicking cartilage gives high durability to cross-linked polyethylene. $4^{\text {th }}$ International Meeting UHMWPE for arthroplasty: From powder to debris; Torino, Italy 2009.

(C) Gómez-Barrena et al.; Licensee Bentham Open.

This is an open access article licensed under the terms of the Creative Commons Attribution Non-Commercial License (http://creativecommons.org/licenses/by-nc/ $3.0 /$ ) which permits unrestricted, non-commercial use, distribution and reproduction in any medium, provided the work is properly cited. 